\title{
Establishment of Character Through Boarding School Education in Students in Pondok Pesantren
}

\author{
Babby Hasmayni \\ Faculty of Psychology Universitas \\ Medan Area \\ North Sumatera, Indonesia
}

\author{
Farida Hanum Siregar \\ Faculty of Psychology Universitas \\ Medan Area \\ North Sumatera, Indonesia
}

\author{
Azhar Aziz \\ Faculty of Psychology Universitas \\ Medan Area \\ North Sumatera, Indonesia
}

\begin{abstract}
- this study aims to create a description of the formation of character through boarding school education in students in pondok pesantren (Islamic Boarding School) and to see the achievement of pesantren in instilling the value of these characters. The values of characters to be seen and implanted such as religious values, discipline, intelligence, helping others, honesty and responsibility. Character is a habit or behavior of a person. The value of the character implanted to students by way of boarding school. In this study, four respondents who previously had bad character values such as not performing the prayers, denied the parents, did not care about the environment and wished to win themselves, but after Islamic boardingschool changed the value of the character for the better. The four respondents were two male students and two female students. Planting the value of these characters to the students by controlling, supervising and doing habituation to the existing routine in the pesantren environment. This research is a qualitative research using unstructured interview technique and observation. The results showed that the four respondents experienced a change and already have the value of existing characters on boarding school (pesantren) is.
\end{abstract}

Keywords- boarding;school;character; building; Islamic

\section{INTRODUCTION}

As the development of technology and information and the flow of globalization have a significant impact on patterns of interaction among humans, especially in the field of education. Every day there are alternating media to feed the news of immoral acts. Changing television and newspaper media reported on such crimes, such as gambling, rape, student brawls, murder, drugs, free sex, robbery and pornographic video cases which turned out that most of the perpetrators were children and adolescents [1].

Coupled with the globalization in the fields of culture, ethics and morals supported by advances in technology and transportation, it has had a positive and negative impact on the nation. On the negative impact, for children who cannot take advantage of technological advances they will fall into behaviors that deviate from religion and result in a moral crisis in the nation's children.

Reference [2] said that the younger generation is currently really under threat. This can be seen from the waning character of empathy and social care for others so that students both in the social environment and in the school environment are more concerned with personal interests or group interests. This can create a harmonious learning environment, a feeling of togetherness that is increasingly fading and an increasingly strong individualist attitude.

Children today come to school with problematic behavior and also problems in attitude. It can be seen the symptoms of damage to the character of the nation's generation in the practice of student manners. The language used by students no longer reflects the national identity that upholds ethics and gentleness. Of course character education is needed which is one of the needs that must be applied at every level of education. This is in line with the opinion of Budianingsih in [2] who argues that moral coaching in the school environment becomes responsible for educators, not only the responsibility of religious groups, but also the responsibility of all teachers / educators, and not to be left behind by the parties others related to the education process at school.

Many educational institutions can develop and realize the goals and functions of national education by implementing character education. One of them is boarding school (boarding school), Islamic based school management (madrasa) and integrated school [2]. One of the school management that supports the formation of student character is the boarding school system.

Boarding school is an educational institution that has a primary focus on character building. Boarding schools whose overall education pattern is more likely to create an ideal educational environment and give birth to people who can bring carriages and motorbikes to the movement of social, political, economic and religious life [3].

According to [4] students who study on a boarding school basis will be controlled by their activities and trained togetherness, social and character, because they are accompanied by a boarding teacher. Dormitory teachers who will assist in developing their positive character in accordance with the vision and mission of each boarding school and also in line with national education goals. 
Therefore boarding school/pesantren education is one suitable place to educate a child to have a commendable attitude and behavior. Where with them going to school with a dormitory system, students will be controlled and maintained from the influence that is outside the school environment.

Based on the results of preliminary observations made at the Integrated Islamic Boarding School Al-Azhar is known to have quite good achievements in the past 2 years. Although the Al-Azhar Integrated Islamic Boarding School (Dayah) is a school that has only been established for the past 3 years, they have been able to achieve brilliant achievements both at the District level and especially to get the best achievements at the District level.

\section{LITERATURE REVIEW}

\section{A. Understanding Character}

According to the Big Indonesian Dictionary, the term character means psychological, moral or character traits that distinguish a person from others.Another opinion states that the term character comes from the Greek charassein, which means making sharp or making in [1].So character is a trait or behavior that is owned by someone who can be observed based on the behavior that appears and which blocks one another.According to Koehler and Royer in [5] specifying character traits IS caring, open, able to manage emotions, have strength, and be consistent with the standards that have been made.

Character values that Ministry of National Education determines there are 18 character values, namely: Religious, Honest, Tolerance, Discipline, Hard work, Creative, Independent, Democratic, Curiosity, Nationalism and nationalism, Love of the country, Respect for achievements, Communicative, Love peace, love to read, care for the environment, care for the social, and responsibility.

Forming character with aottom up approach - approaches that use the path from the bottom up and starting with oneself - must be designed as well as possible. In the elaboration, a philosophy is described through three operational bases that will become references [6].

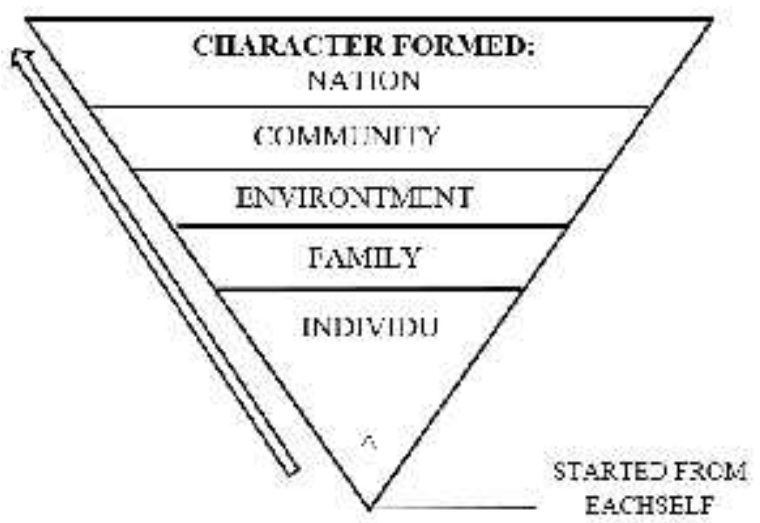

Fig 1. Mindset Forms Character in Bottom Up
The mindset above is implemented through elaboration illustrated in the following figure that illustrates how philosophy is translated through three operational foundations. If observed carefully the image

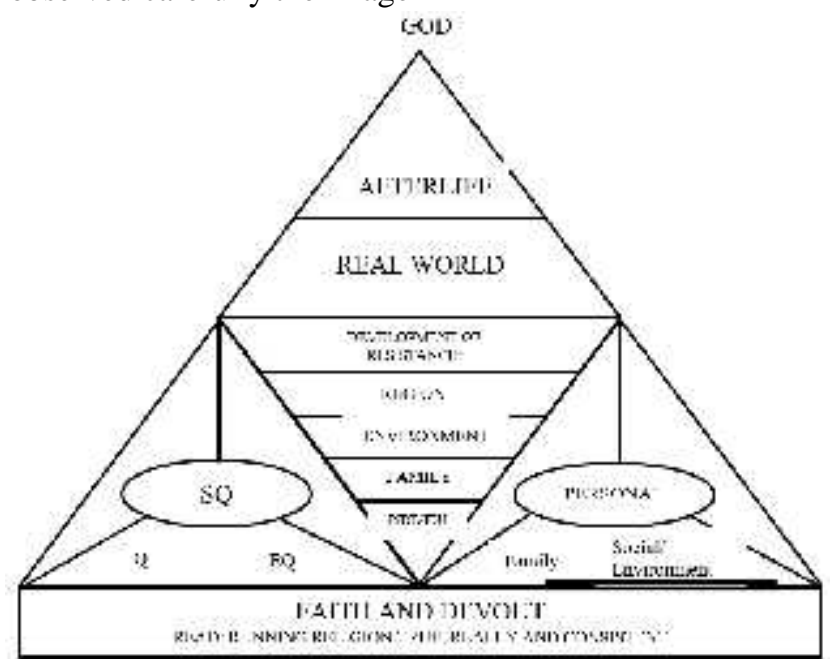

Fig 2. Philosophy and Oprational Foundation of Character Building in Bottom Up According to Soedarsono

\section{B. Educational Boarding School}

Boarding school is an English word consisting of two words namely boarding and school, boarding means riding and school means school, then absorbed into Indonesian into a boarding school [3]. It has characteristic. and the characteristics of Islamic boarding schools according to [8] that hold classical teaching (madrasy) and teaching by scholars are application and given at certain times, namely:

- The santri live in the cottage / ma'had.

- Guide between the original learning patterns of pesantren and the madrasa / school system.

- There is a clear curriculum.

- Have a special place that functions as a school / madrasah.

Beside that, the dimensions of qality for boarding schools according to [9] stated that the quality dimension for Islamic boarding schools consisted of, Reliability, Responsiveness, Assurance, Empathy, Direct Evidence, and Tangibles.

\section{METHODOLOGY}

In accordance with the above problem, in this study the phenomenological approach was seen as more appropriate to know in depth about character formation through boarding school education in students in boarding schools.In this study, the characteristics of the respondents chosen were students who were still in school and at least two years of schooling.

In this study using 4 respondents namely 2 male students and 2 female students and using 1 informant for 1 respondent. Respondent retrieval techniques using purposive sampling 
method. This study uses interview and observation methods. In adding data and information, a tool is used in the form of Informed Consent and Recorder.

To maintain the continuity and validity of the research, the researchers used data triangulation, researcher triangulation, and triangulation methods.

\section{RESULTS AND DISCUSSION}

\section{A. Results}

The results of this study were obtained by direct observation of 4 respondents. Observations were made to explore the values of the character of the respondents; religious, discipline, helping others, intelligence, honesty, and responsibility. By using informed consent and recording equipment obtained the results of the following research are summarized in Table. 1.

TABLE I. RESULTS OF RESPONDENTS INTERPERSONAL ANALYSIS RECAPITULATION

\begin{tabular}{|c|l|l|}
\hline \multirow{2}{*}{ No } & \multirow{2}{*}{$\begin{array}{c}\text { Character } \\
\text { Values }\end{array}$} & \multicolumn{1}{|c|}{ Conclusions from respondents } \\
\cline { 3 - 4 } I $^{\mathrm{st}}$ & Religious & $\begin{array}{l}\text { The four respondents have religious values such as } \\
\text { praying, reading the Qur'an and wearing a } \\
\text { headscarf }\end{array}$ \\
\hline 2 & Discipline & $\begin{array}{l}\text { The value of discipline is in the four respondents, } \\
\text { such as obeying the rules, praying on time, reading } \\
\text { the Qur'an after prayer }\end{array}$ \\
\hline 3 & $\begin{array}{l}\text { Helping } \\
\text { Others }\end{array}$ & $\begin{array}{l}\text { The value of helping others is owned by the four } \\
\text { respondents }\end{array}$ \\
\hline 5 & Intelligence & $\begin{array}{l}\text { Intelligence character values have been possessed } \\
\text { by the four respondents such as apologizing, using } \\
\text { leisure time well }\end{array}$ \\
\hline 6 & Honesty & $\begin{array}{l}\text { The value of honesty character is only the second } \\
\text { respondent who has such an honest use of money } \\
\text { when asked more }\end{array}$ \\
\hline Responsible & $\begin{array}{l}\text { The character value of responsibility has been } \\
\text { possessed by all four respondents who dare to } \\
\text { accept the consequences of all actions, and carry } \\
\text { out their duties well. }\end{array}$ \\
\hline
\end{tabular}

Source: Data Analisys

\section{B. Discussion}

Based on the research that has been done on the four respondents, the results show that the four respondents experienced a change in character values for the better and had character values applied in the Al-Azhar Islamic boarding school environment. Where before they entered the environment the four boarding schools of respondents did not have good character values. Two respondents (1 and 2) were students who were from the beginning of the school at this AlAzhar boarding school while those who were respondents (3 and 4) were transfer students. The third respondent is a transfer student from another pesantren in Aceh, while the fourth respondent is a transfer student from a public school.

In carrying out life in an Islamic boarding school environment, the four respondents were always filled with many activities that became routine in their daily lives. In fact, it was not uncommon for the santri and respondents to get punishments when they committed violations. Penalties were given with the aim that the santri felt deterred from committing an offense. According to [10] penalties in the education process, namely punishment is the reward given or intentionally caused by someone (parent, teacher, etc.) after a violation, crime or mistake occurs

In the opinion of [8] defines punishment as an act that is taken to the child consciously and intentionally so as to cause suffering, so that the child will become aware and promise not to repeat it. This is in accordance with the reality obtained by the santri, for example the santri committing a violation did not attend the prayer on time so that the santri would get a penalty for cleaning the bathroom. After getting the sentence the santri felt deterred from committing the violation.

Punishment that santri can when committing a violation is like being bathed, standing on a flagpole with respect, cleaning the bathroom, bald head, wearing jamilah clothes (colorful clothes) while wearing posters hung on the neck. Apart from getting punishment from the ustad santri, they also received supervision from the ustad in carrying out activities in the pesantren environment. The observation carried out is so that the santri and respondents are accustomed to carrying out existing activities without the need to be monitored by the clerics.

The character values applied in the Al-Azhar Islamic boarding school environment have been embedded in the respondents, namely:

\section{1) Religious}

The main value in the Islamic boarding school environment is religious value. Islamic boarding schools which act as a forum for the formation of people who are full of religious values. Ministry of National Education [7] said that religious is obedience and obedience in understanding and carrying out the teachings of the religion adhered to. After living and carrying out daily life in the pesantren environment, the four respondents had the value of religious character. The four respondents have now implemented religious teachings such as praying and reading the Qur'an. Whereas the fourth respondent has now been wearing headscarves and polite clothes when leaving the house.

The above is in accordance with the opinion of [5], stating that religiosity in religious terms is manifested in various human lives, whether it concerns ritual behavior (worship) or other activities in life (which are colored by religious nuances), both those that appear and can be seen by the eye or unseen (occurring in the human heart). Of the four respondents, the four respondents now have the value of this religious character in which in the day-to-day respondents have fasted, recited, and performed fard prayers and sunnah prayers. 


\section{2) Discipline}

Discipline is one of the values held firmly in the life of the pesantren with the value of discipline that will make the santri become the person who has responsibility. According to [11] discipline can be shaped by determining the schedule of activities, rules, and witnesses who are not in school.

The four respondents prayed in congregation at the mosque, because the pesantren required all santri to pray in congregation. The four respondents also always pray at the mosque in a timely manner.

\section{3) Helping others}

During his stay in the boarding school environment is always filled with social life between santri and religious teachers/religious teachers and other students because living in an Islamic boarding school means far from parents.

\section{4) Intelligence}

The fourth value in the pesantren environment is intelligence. According to [11] students need to use intelligence or reason and mind in acting. The four respondents if they have free time, they always use it to study and do assignments. In the third and fourth respondents if they make mistakes for what they do, the two respondents want to apologize for the mistakes they made.

\section{5) Honesty}

Living in a cottage environment makes the santri have a lot of routines that they have to do, so that the santri must be disciplined and honest in carrying out their routines. According to [11] honesty is to report worship activities and learn according to what is done.

\section{6) Responsibility}

In our daily lives we must be responsible for all the actions we take. The responsibility according to [11] is to carry out activities that are tasks assigned to him. Of the four respondents, they have a value of responsibility for what is given and for all of their actions

\section{CONCLUSION}

- The character values applied in the Al-Azhar Islamic Boarding School environment are religious values, discipline, helping others, intelligence, honesty and responsibility.

- Of all the values in the boarding school environment, the four respondents already had the whole score. This can be seen with the activities that become the routines of the respondents in the Islamic boarding school environment

- In planting character values to the santri the method used is by giving punishment to the santri, so that the santri are consistent in applying the character's values.
- In addition to using the punishment method, other methods used in planting character values to santri are by way of habituation and supervision. These three methods are carried out on an ongoing basis so that the character values to be implanted can be embedded well in the santri. With supervision, the santri will feel supervised and unwilling to commit violations.

\section{REFERENCES}

[1] Saptono. 2011. Dimensi-dimensi Pendidikan Karakter (Wawasan, Strategi, dan Langkah Praktis). Jakarta. Esensi Erlangga Grup

[2] Hendriyanti, 2014, Pelaksanaan Program Boarding School Dalam Pembinaan Moral Siswa Di SMA Taruna Indonesia Palembang. Ta'dib, Vol XIX, No 2, Hal. 203-226

[3] Rizkiani, Anisa., 2012. Pengaruh Sistem Boarding School Terhadap Pembentukan Karakter Peserta Didik (Penelitian Di Ma'had Darul Arqam Muahammadiyah Daerah Garut). Jurnal pendidikan Universitas Garut. Vol 06. No 01. Hal 10-18

[4] Khalidy, Shadiq, dkk. 2014. Pengelolaan Pendidikan Karakter Berbasis Boarding School Di SMP. Jurnal Manjemen Pendidikan. Vol 9. No 1. Hal 77- 84

[5] Lestari, Sri. 2014. Psikologi Keluarga (Penerapan Nilai Dan Penanganan Konflik Dalam Keluarga). Jakarta. Kencana Prenadamedia Group

[6] Hasmayni, B; \& Simatupang, H. 2012. Perbedaan Minat Sekolah dan Motivasi Belajar Ditinjau Dari Pola Asuh Orangtua. Jurnal Magister Psikologi UMA (Analitika). Vol IV No 1 Hal 24-30. Medan Pasca Psikologi UMA

[7] Rizkiani, Anisa., 2012. Pengaruh Sistem Boarding School Terhadap Pembentukan Karakter Peserta Didik (Penelitian Di Ma'had Darul Arqam Muahammadiyah Daerah Garut). Jurnal pendidikan Universitas Garut. Vol 06. No 01. Hal 10-18

[8] Hamid, Abdulloh. 2017.Pendidikan Karakter Berbasis Pesantren (Pelajar dan Santri dalam Era IT dan Cyber Culture). Surabaya; Imtiyaz

[9] Halim, A. dkk. 2005. Manajemen Pesantren. Yogyakarta: Pustaka Pesantren

[10] Purwanto, M. Ngalim. 2014. Ilmu Pendidikan Teoretis dan Praktis, Edisi Kedua. Bandung. PT Remaja Rosdakarya.

[11] Sani, Ridwan Abdullah. 2016. Pendidikan Karakter (Mengembangkan Karakter Anak Yang Islami). Jakarta; PT Bumi Aksara 